\title{
Developments
}

\section{Euratom, the European Court of Justice, and the Limits of Nuclear Integration in Europe}

\author{
By Sebastian Wolf
}

\begin{abstract}
Es muss daher vorrangig die Abschaffung des EuratomVertrags gefordert werden. ${ }^{1}$

Machen wir die Gegenprobe und denken den EuratomVertrag für eine logische Sekunde weg.... Der gemeinsame rechtliche verbindliche Ordnungs- und Disziplinierungsrahmen der Kernkraft entfiele und die antinuklearen Mitgliedstaaten wären auf sich allein gestellt. ${ }^{2}$
\end{abstract}

\section{A. Introduction}

Only a few European integration experts know that Jean Monnet, one of the masterminds of the European Coal and Steel Community, strongly preferred the European Atomic Energy Community ${ }^{3}$ to the European Economic Community in the 1950 s and 1960 s. From his point of view, sectoral and technical cooperation in the field of nuclear energy seemed to be much more promising in order to foster European integration than cross-sectoral economic integration. Monnet and others believed that nuclear energy could, inter alia, solve all energy supply problems, would revolutionize research and technical development,

\footnotetext{
- The author is a postdoctoral researcher at the University of Konstanz (Konstanz, Germany) and the LiechtensteinInstitut (Bendern, Llechtenstein), and lecturer at the University of Liechtenstein (Vaduz, Liechtenstein). Email: sebastian.wolf@uni-konstanz.de.

${ }^{1}$ Erwin Mayer \& Franko Petri, Europälsche Kernschmelze, in DAS KRITISCHE EU-BUCH, 217, 228 (Attac ed., 2006) ("Thus it is a priority to demand the abolishment of the Euratom Treaty").

2 Jürgen Grunwald, New Treaty, no Treaty or Status Quo? Expert hearing in the European Parliament 5 (1 Feb. 2007), http://www.europarl.europa.eu/hearings/20070201/itre/grunwald_de.pdf ("Let's do a cross-check and assume away the Euratom Treaty for a second.... The common legally binding framework for regulating and disciplining nuclear power would not exist and the anti-nuclear member states would be on their own").

${ }^{3}$ Treaty Establishing Euratom, 25 Mar. 1957, 2010 O.J. (C84) 1 [hereinafter Euratom Treaty].
} 
and could contribute to unifying the peoples of Europe in a few decades. ${ }^{4}$ However, nuclear energy in general and Euratom in particular have belied these expectations.

Today, nuclear power plants provide significantly less than half of the electric energy produced in the EU. ${ }^{5}$ Most European countries do not plan to build new nuclear power plants. ${ }^{6}$ Supranational research on nuclear issues has not superseded national research apart from some cost-intensive projects. ${ }^{7}$ Maybe Euratom's most important achievements so far are the uniform safety standards on radiation protection enacted after the Chernobyl disaster ${ }^{8}$ and obligations for new Eastern European member states to either comply with certain safety standards regarding nuclear installations or to shut down their Soviet-style reactors. ${ }^{9}$ The governments of the EU member states usually strongly disagree when it comes to nuclear energy issues. ${ }^{10}$ Therefore, the Euratom Treaty, unlike the other EU founding treaties, has never been amended in substance. ${ }^{11}$ Nuclear energy is mostly seen as a national policy issue-most Europeans have never heard of Euratom. Thus, some observers call the EAEC the "failed Community." ${ }^{12}$ It particularly failed to unify the peoples

\footnotetext{
${ }^{4}$ See françols duchene \& Jean Monnet, The first Statesman of Interdependence 292-99 (1994); Jean MonNet, MÉmoIRES 492, 469-71, 490-93 (1976). On the nuclear euphoria of the 1950s, see, for example, Manfred Kriener, Das atomare Glück, 66 DIE ZEIT 84 (14 Sept. 2006) and compare Euratom Treaty, supra note 3, pmbl.

5 See EuRopean Comm'N, Report, SPecial Eurobarometer 324, Europeans and Nuclear Safety 80 (March 2010) [hereinafter EUROBAROMETER].

${ }^{6}$ Id. at 85 .

${ }^{7}$ On the ITER project (International Thermonuclear Experimental Reactor), see Sebastian Wolf, Integration durch Kernfusion? Zur Wiederbelebung der Euratom-Gründungsmythen, 25 FORUM RECHT 26 (2007).

${ }^{8}$ See Jürgen Grunwald, Tschernobyl und das Gemeinschaftsrecht, 21 EUROPARECHT 315 (1986).

9 Jürgen Grunwald, Der Euratom-Vertrag: nie war er so wertvoll wie heute, 11 EUROPÄISCHE ZEITSCHRIFT FÜR WIRTSCHAFTSRECHT 481 (2000).

10 See Raphael Sauter, EU-Agenda-Setting und europäische Energiepolitik: Das "EU-Nuklearpaket," 38 ÖSTERREICHISCHE ZEITSCHRIFT FÖR POLITIKWISSENSCHAFT 453 (2009).

${ }^{11}$ As a consequence, the European Parliament's legislative powers under the Euratom Treaty have never been strengthened, and the EAEC is mainly governed by the Council (major (non-)decisions) and the European Commission (day-to-day politics). Even the Treaty of Lisbon only adapted the Euratom Treaty's institutional and financial provisions to the EU's new legal framework (see the consolidated Treaty, supra, note 4). That is why the EASC is still a political reality (Art. 208 Euratom Treaty provides that "This Treaty is concluded for an unlimited period"). After the EU absorbed the European Community and its legal personality due to the Lisbon Treaty, the EAEC is the only European founding Community left. On possible amendments of the Euratom Treaty, see Nuria Prieto Serrano, Wakening the serpent: reflections on the possible modification of the Euratom Treaty, 1 INT'L J. NuCLEAR L. 11 (2006) and Sebastian Wolf, Zur Zukunft des Euratom-Vertrags, 29 INTEGRATION 297 (2006).
}

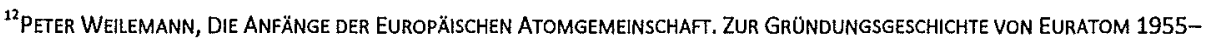
1957157 (1983). Especially civil society actors and green parties call for abolishing the EAEC or unilateral withdrawing from the Euratom Treaty (see e.g. Mayer \& Petri, supra, note 1). 
of Europe: While a slight majority of European citizens oppose nuclear energy, attitudes considerably vary from country to country. ${ }^{13}$

In the last decades, there have not been many cases in which the European Court of Justice (ECJ) or the General Court (i.e. the former Court of First Instance) had to deal with substantial Euratom law. ${ }^{14}$ Most of these cases are similar and rather unspectacular actions initiated by the European Commission for declaration of a failure of a member state to fulfill its obligations under certain Euratom directives. The Temelin judgment, ${ }^{15}$ however, is a "milestone decision" ${ }^{16}$ with significant political implications. It is about the important question of who ultimately decides the level of nuclear radiation protection in the EU multi-level system. This article, at the intersection of political science and law, takes the Temelin case as a starting point to analyze different modes of governance that represent diverging approaches to deal with such a transnational issue of high political salience. If the EU takes into account the perceptions and demands of the people, it will probably gain acceptance and legitimacy. However, the EU institutions will not contribute to sustainable European integration in this policy field if they ignore the citizens' attitudes regarding nuclear safety. ${ }^{17}$

This paper first summarizes the Temelin case, which is barely known even by many European integration experts (Part B.). The following section contains a short critique of the judgment (Part $\mathrm{C}$.). The rest of the article will focus on the decisive political question (Part D.) underlying the Temelin case. Drawing on the arguments of the actors involved in the Temelin case, four competing modes of governance can be distinguished (Part E.): unilateralism (Part E.I.), hierarchical supranationalism (Part E.II.), deliberative nationalism (Part E.III.) and deliberative supranationalism (Part E.IV.). The concluding section tries to outline a framework that could bring political actors to behave in a deliberative way in conflicts such as the Temelín dispute (Part F.). Due to the recent serious accident at the Fukushima nuclear power plant, an epilog discusses the governance of nuclear emergencies in the context of Euratom (Part G.).

\footnotetext{
${ }^{13}$ EUROBAROMETER, supra note 5, at 40-73. See also infra Part B.

${ }^{14}$ The author has detected only 27 cases involving substantial Euratom law since 1990.

${ }^{15}$ Case C-115/08, Oberösterreich v. ČEZ as, 2009 E.C.R. 1-10265 [hereinafter Temelín case].

${ }^{16}$ Wolf-Georg Schärf, The Temelin-Judgement of the European Court of Justice, 85 NUCLEAR L. BULL. 79 (2010).

${ }^{17}$ On the necessity to protect (non-discriminatory) member state core policies and values in order to preserve legitimacy in the EU, see Fritz W. Scharpf, Legitimacy in the Multilevel European Polity (MPIfG Working Paper No. 09/1 2009).
} 


\section{B. The Temelin Case}

The dispute about the safety of the Temelin nuclear power plant involves several actors in Austria (specifically the federal government, the Land Oberösterreich and private parties) and the Czech Republic (specifically the central government and ČEZ, the company operating the power station). Before presenting the facts of the case (Part B.I.) and the ECJ's judgment (Part B.II.), it seems useful to have a look at the different perceptions of the people in Austria and the Czech Republic regarding nuclear energy.

Table 1: Perceptions of Nuclear Safety in Austria and the Czech Republic ${ }^{18}$

\begin{tabular}{|c|c|c|}
\hline & Austria & Czech Republic \\
\hline $\begin{array}{l}\text { When you think about nuclear power, what first comes to mind? } \\
\text { The risks of nuclear power as an energy source outweigh its benefits } \\
\text { The benefits of nuclear power as an energy source outweigh the risks } \\
\text { it poses }\end{array}$ & $\begin{array}{l}65 \% \\
24 \%\end{array}$ & $\begin{array}{l}39 \% \\
59 \%\end{array}$ \\
\hline $\begin{array}{l}\text { In your opinion, compared to other safety risks in our lives, would you say } \\
\text { that nuclear risks are ...? } \\
\text { Strongly exaggerated/somewhat exaggerated } \\
\text { Somewhat underestimated/strongly underestimated }\end{array}$ & $\begin{array}{l}24 \% \\
51 \% \\
\end{array}$ & $\begin{array}{l}52 \% \\
43 \% \\
\end{array}$ \\
\hline $\begin{array}{l}\text { To what extent do you think that (the) nuclear power plant(s) in your country } \\
\text { represent(s) a risk to you and your family? } \\
\text { A big risk/some risk } \\
\text { Not much of a risk/no risk at all }\end{array}$ & $\begin{array}{l}60 \%{ }^{19} \\
20 \% \\
\end{array}$ & $\begin{array}{l}45 \% \\
54 \% \\
\end{array}$ \\
\hline $\begin{array}{l}\text { It is possible to operate a nuclear power plant in a safe manner } \\
\text { Totally agree/tend to agree } \\
\text { Tend to disagree/totally disagree }\end{array}$ & $\begin{array}{l}33 \% \\
63 \% \\
\end{array}$ & $\begin{array}{l}74 \% \\
22 \% \\
\end{array}$ \\
\hline $\begin{array}{l}\text { The nuclear safety authority in your country sufficiently ensures the safe } \\
\text { operation of nuclear power plant(s) } \\
\text { Totally agree/tend to agree } \\
\text { Tend to disagree/totally disagree }\end{array}$ & $\begin{array}{l}42 \% \\
48 \% \\
\end{array}$ & $\begin{array}{l}74 \% \\
20 \% \\
\end{array}$ \\
\hline $\begin{array}{l}\text { Your national legislation sufficiently ensures nuclear safety } \\
\text { Totally agree/tend to agree } \\
\text { Tend to disagree/totally disagree }\end{array}$ & $\begin{array}{l}49 \% \\
43 \%\end{array}$ & $\begin{array}{l}63 \% \\
27 \%\end{array}$ \\
\hline $\begin{array}{l}\text { You trust companies operating nuclear power plants } \\
\text { Totally agree/tend to agree } \\
\text { Tend to disagree/totally disagree }\end{array}$ & $\begin{array}{l}26 \% \\
72 \%\end{array}$ & $\begin{array}{l}69 \% \\
29 \%\end{array}$ \\
\hline
\end{tabular}

${ }^{18}$ EUROBAROMETER, supra note 5 , at $41,46,49,54,56,59,62,63,66,67,71$ (table compiled by the author).

${ }^{19}$ It should be noted that there are no nuclear power plants in Austria apart from a research reactor. A federal law enacted after a referendum as well as a federal constitutional law prohibit the construction of nuclear power stations in Austria. See Waldemar Hummer, Temelin: Das Kernkraftwerk an der Grenze, 63 ZEITSCHRIFT FÖR ÖFFENTLICHES RECHT 501, 506 (2008). 


\begin{tabular}{|l|l|l|}
\hline $\begin{array}{l}\text { The disposal of radioactive waste can be done in a safe manner } \\
\text { Totally agree/tend to agree } \\
\text { Tend to disagree/totally disagree }\end{array}$ & $26 \%$ & $65 \%$ \\
\hline $\begin{array}{l}\text { Nuclear power plants are sufficiently secured against terrorist attacks } \\
\text { Totally agree/tend to agree }\end{array}$ & $69 \%$ & $30 \%$ \\
Tend to disagree/totally disagree & $24 \%$ & $51 \%$ \\
\hline Nuclear materials are sufficiently protected against malevolent use & $69 \%$ & $39 \%$ \\
Totally agree/tend to agree & $27 \%$ & $61 \%$ \\
Tend to disagree/totally disagree & $67 \%$ & $30 \%$ \\
\hline $\begin{array}{l}\text { Personally, taking into account all that you know about this topic, thinking } \\
\text { about you and your family, do you see nuclear energy more as a benefit or } \\
\text { more as a risk? }\end{array}$ & \\
More as a risk & $75 \%$ & \\
More as a benefit & $13 \%$ & $66 \%$ \\
\hline
\end{tabular}

\section{The Context of the Dispute}

In the words of the ECJ, the facts of the Temelin case can be summarized as follows: ${ }^{20}$

The Land Oberösterreich is the owner of land used for agriculture and agricultural trials, on which there is an agricultural college. The land is situated about $60 \mathrm{~km}$ from the Temelín nuclear power plant, which itself is situated in the Czech Republic, $50 \mathrm{~km}$ from the Austrian border. That power plant is operated by... ČEZ, a limited company incorporated under Czech law in which the Czech State holds a majority share. The construction and operation of the Temelín nuclear power plant were authorized by the Czech authorities in 1985 and it began operating on a trial basis on 9 October 2000. In 2001, the Land Oberösterreich and other private owners brought actions before the Landesgericht Linz pursuant to Paragraph 364(2) of the $A B G B$, seeking an order that ČEZ put an end to the actual or potential nuisance relating to the ionising radiation potentially emanating from that power plant. According to the Land Oberösterreich, the radioactivity generated by the normal functioning of that nuclear power plant or, in any event, the risk of contamination caused by the operation and potential malfunction of

\footnotetext{
${ }^{20}$ For additional information and numerous references, see id. at 523-51.
} 
the plant cause a lasting interference with the normal use of its land....

The Temelin facility was, moreover, the subject of negotiations between the Republic of Austria and the Czech Republic...those two States adopted a document known as 'The Conclusions of the Melk Process and Follow-Up', referred to inter alia in the joint declaration...concerning their bilateral agreement relating to the Temelín nuclear power plant, annexed to the final act of the Treaty concerning the accession of 10 new Member States, ... in which both States declared that they would fulfil the series of bilateral obligations set out in those conclusions. Since 2003, the Temelin nuclear power plant has operated at full capacity.

According to...the Commission..., in the negotiations leading up to the accession of ten new Member States in 2004, particular attention was directed to the questions of nuclear safety at the power plants in the candidate States.... The ... safety of the Temelín nuclear power plant was evaluated by the Commission and the Council, ... and the results of that evaluation showed that the Temelín nuclear power plant, subject to the implementation of the proposed recommendations, showed a satisfactory level of nuclear safety...

Moreover, ... . since the accession of the Czech Republic to the European Union, checks have been carried out at Temelín in 2004 and in 2005, pursuant to Article 35 EA. ${ }^{21}$. The Commission also issued an opinion... concerning the plan for the disposal of radioactive waste resulting from modifications at the site of the Temelin nuclear power plant... the Commission concluded inter alia that the implementation of the plan for the disposal of

\footnotetext{
${ }^{21}$ Art. 35 Euratom Treaty provides: "(1) Each Member State shall establish the facilities necessary to carry out continuous monitoring of the level of radioactivity in the air, water and soil and to ensure compliance with the basic standards. (2) The Commission shall have the right of access to such facilities; it may verify their operation and efficiency." Euratom Treaty, supra note 3 , art. 35.
} 
radioactive waste in whatever form ..., both in normal operation and in the event of an accident..., is not liable to result in radioactive contamination, significant from the point of view of health, of the water, soil or airspace of another Member State'. On 3 November 2006, the two reactors of the Temelín power plant were inspected and found to be compliant with the prevailing legislation; a definitive declaration was issued to that effect. ${ }^{22}$

\section{The EC's Judgment}

In its reference for a preliminary ruling, the Landesgericht Linz (District Court of Linz) stated that according to $\S 364 a A B G B$ (Austrian Civil Code), as interpreted by the Oberster Gerichtshof (Austrian Supreme Court), installations such as power plants operating on the basis of foreign authorizations could be the subject of actions for injunctions to prevent nuisances to neighboring property. In contrast, installations authorized by Austrian authorities could only be the subject of claims for compensation for damage caused to neighboring property. The Landesgericht mainly asked the ECJ-by way of not less than 19 lengthy questions - whether such a discriminatory treatment is an infringement of Articles $10,12,28$ and/or 43 EC Treaty. ${ }^{23}$

The findings of the Court can be summarized in a nutshell: The ECJ first noted that operating a nuclear power plant is an industrial activity that falls within the scope of application of the Euratom Treaty. ${ }^{24}$ Then the Court argued "that although the principle of prohibition of any discrimination on grounds of nationality within the scope of application of Community law is expressly laid down only in Article $12 \mathrm{EC}$, it is a general principle which is also applicable under the EAEC Treaty." ${ }^{25}$ After that the ECJ declared that the discrimination contained in the Austrian law in question "leads to the same outcome as a difference in treatment on grounds of nationality." ${ }^{26}$ This discriminatory treatment "does come within the scope of application of the EAEC Treaty." ${ }^{27}$ According to the Court, such a discrimination cannot be "justified on grounds of protecting life, public health, the

\footnotetext{
${ }^{22}$ Temelin, paras. 38-49 (shortened by the author; line breaks modifted by the author).

${ }^{23} / d$. at paras. $50-54$.

${ }^{24} /$ dd. at para. 83.

${ }^{25}$ Id. at para. 91.

${ }^{26} / d$. at para. 97.

${ }^{27} / d$. at para. 107.
} 
environment or property rights" ${ }^{28}$ because "the Community legislative framework [i.e. Euratom's health and safety policy]... contributes precisely and essentially towards ensuring such protection. ${ }^{29}$ Therefore the ECJ finally ruled

that the principle of prohibition of discrimination on grounds of nationality within the scope of application of the EAEC Treaty precludes the application of the legislation of a Member State, such as that at issue in the main proceedings, under which an undertaking in possession of the necessary official authorisations for operating a nuclear power plant situated in the territory of another Member State, may be the subject of an action for an injunction to prevent an actual or potential nuisance to neighbouring property emanating from that installation, whereas undertakings having an industrial installation situated in the Member State where the action is brought and in possession of an official authorisation may not be the subject of such an action and may only be the subject of a claim for damages for harm caused to a neighbouring property. ${ }^{30}$

\section{A Short Critique of the Judgment}

The Court rightly found that the Temelin dispute falls within the scope of application of the Euratom Treaty. ${ }^{31} \quad$ Neither the Land Oberösterreich and the Landesgericht Linz nor Advocate General Maduro ${ }^{32}$ realized that EAEC law is decisive in this case; this demonstrates once again that Euratom is hardly visible and its law is unknown to many legal experts. However, the ECl's key findings are only partly convincing. On one hand, it is questionable whether the potential discriminatory treatment of the Austrian law in question is an infringement of Euratom law (Part C.I.). On the other hand, even if $\S 364 a$ $A B G B$ implies undue difference in treatment, it is debatable whether it cannot be justified on grounds of protecting public health (Part C.II.).

\footnotetext{
${ }^{28} / d$. at para. 135.

${ }^{29} / d$. at para. 136.

${ }^{30} / d$. at para. 139.

${ }^{31}$ Schärf, supra note 16, at 91; see also Wolf-Georg Schärf, Case Note, Anmerkung, 21 EUROPÄISCHE ZEITSCHRIFT FüR WIRTSCHAFTSRECHT 33 (2010).

${ }^{32}$ See Temelin, Opinion of Advocate General Poiares Maduro, para. 13.
} 


\section{Illicit Discrimination Under Euratom Law?}

In the particular field of nuclear energy policy, the Euratom Treaty created a self-contained regime. ${ }^{33}$ Some authors - and maybe also the ECJ-seem to underestimate or neglect this fact. They argue that the EAEC Treaty is a rather limited lex specialis with regard to the EC/TFEU Treaty. From this point of view, EU/EC law is applicable also in the nuclear sector if specific Euratom provisions do not exist or are incomplete. ${ }^{34}$ Moreover, this approach could even imply a hierarchy of norms. ${ }^{35}$ However, it has to be emphasized that all "[t]reaties enjoy the same position and binding force in the Community legal system of sources." ${ }^{36}$ If we follow the basic approach that each founding treaty is autonomous, "the notion that the EC Treaty applies (and was meant to apply) 'across the board' to all economic activity (including the nuclear industry) is to be rejected. ${ }^{137}$

In its Temelin judgment, the ECJ mentions the former Art. 305 (2) EC Treaty, which provides that the EC Treaty shall not affect the provisions of the Euratom Treaty. ${ }^{38}$ It rightly notes that the Euratom Treaty does not contain an explicit general prohibition of any discrimination on grounds of nationality. ${ }^{39}$ Nevertheless, the Court decides that Art. 12 EC Treaty (now 18 TFEU) is a "general principle" that also applies to the Euratom Treaty: "It would appear to be contrary to both the purpose and the consistency of the treaties to allow discrimination on grounds of nationality... to be tolerated within the scope of application of the EAEC Treaty.." ${ }^{.00}$ One may see this approach as "the biggest innovation of the judgment." ${ }^{\prime 11}$ However, maybe the member states, as "masters of the treaties," did not want such a consistency of the founding treaties? They established, for example, completely different regulatory regimes in the field of state aids. ${ }^{42}$ As to the issue of

\footnotetext{
${ }^{33}$ Thomas F. Cusack, A Tole of Two Treaties: An Assessment of the Euratom Treaty in Relation to the EC Treaty, 40 COMMON MKT. L. REV. 117, 142 (2003)

${ }^{34}$ See WOLF-GEORG SCHÄRF, EUROPÄISCHES NUKLEARRECHT 166-67 (2008) (citing further references).

${ }^{35} \mathrm{Cf}$. Cusack, supro note 33 , at 127

${ }^{35}$ Serrano, supra note 11 , at 13.

${ }^{37}$ Cusack, supra note 33 , at $127-28$

${ }^{\text {ss }}$ Temelín, para. 85 .

39 Id. at para. 88 .

${ }^{40}$ ld. at para. 90.

${ }^{41}$ Markus Möstl, Case Note, Case C-115/08, Land Oberösterreich v. ČEZ, Judgment of the Grand Chamber of 27 October 2008, 47 COMMON MKT. L. REv. 1221, 1230 (2010); see also Schärf, Anmerkung, supra note 31, at 34.

${ }^{42}$ State alds in the nuclear sector are not prohibited since the Euratom Treaty is based on a different policy approach than the EC/TFEU Treaty. See JÜRGEN GRUNWALD, DAS ENERGIERECHT DER EUROPÄISCHEN GEMEINSCHAFTEN 234239 (2003); Cusack, supra note 33, at 130-40; Serrano, supra note 11, at 13.
} 
discrimination on grounds of nationality, the Euratom Treaty contains some special rules, for example, in the chapter on the nuclear common market (Art. 92-99 Euratom Treaty). The Temelin dispute, lacking a strong "trans-border element," ${ }^{43}$ does not fall within the scope of application of these explicit but rather restricted provisions; only an imported general principle, like the one transferred by the Court, may lead to the ECJ's further findings. Therefore, it is not obvious that the Austrian law in question has to be qualified as an illicit discriminatory treatment under Euratom law. Finally, it should be added that the judicial creation of higher-ranking EU constitutional law that overrides ordinary primary law is questionable from the perspective of democratic legitimacy. ${ }^{44}$

\section{No Possible Justification?}

Even if one accepts the notion that the Austrian Civil Code provision in question means an illicit difference in treatment, there are good reasons to argue that it can be justified on grounds of protecting public health. According to the ECI, a member state has no choice but to recognize authorizations by authorities of other member states if the latter comply with European basic standards of nuclear radiation protection." This is "fairly strict compared to normal recognition cases." ${ }^{\prime 46}$ In contrast, Advocate General Maduro argued that Austrian courts have a certain scope of discretion not to recognize authorizations by authorities of other member states "if such a refusal is non-discriminatory in nature and is properly justified on grounds of public policy, public security or public health and provided that proper account is taken of compliance with relevant Community rules and the interests of all affected parties." ${ }^{177}$ At this point it should be added that it is questionable whether $\S 364 a A B G B$ really implies a discriminatory treatment; the Austrian federal government and the Land Oberösterreich called the respective interpretation of the national law by the Landesgericht Linz into question (while the Court rightly refused to interpret Austrian law). ${ }^{48}$

If there is a difference in treatment, it can perhaps be justified by the fact that the protection of public health against the risks of nuclear radiation is a key element and goal of the Euratom Treaty (which justifies, at least to a certain extent, its continued

\footnotetext{
${ }^{43}$ Möstl, supra note 41 , at 1231.

${ }^{44}$ See Scharpf, supra note 16 , at 18 (explaining that this is particularly the case since the ECJ jurisprudence can hardly be corrected by democratically legitimized institutions).

${ }^{45}$ Temelín, paras. $135-36$.

${ }^{46}$ Möstl, supra note 41, at 1231.

${ }^{47}$ Temelin, Opinion of Advocate General Poiares Maduro, para. 24.

${ }^{48}$ Temelín, paras. 55-57.
} 
existence ${ }^{49}$ ). The Preamble of the EAEC Treaty provides that the member states are "anxious to create the conditions of safety necessary to eliminate hazards to the life and health of the public." The health and safety chapter (Art. 30-39 Euratom Treaty) and other treaty provisions contain several strong competences to implement such a policy, as the Court noted. ${ }^{50}$ However, the EAEC only provides basic standards for the protection against ionizing radiations (Art. 30-33 Euratom Treaty). It is possible and sometimes compulsory to take additional measures (e.g. Art. 34, 38 Euratom Treaty). In 1992, the ECJ ruled that the "obligation imposed on the Community by Article 2(b) of the EAEC Treaty to lay down uniform safety standards to protect the health of the population and of workers does not mean that, once such standards have been defined, a Member State may not provide for more rigorous protection." ${ }^{51}$ The Court had not restricted this remarkable notion to any legal or factual conditions. In its Temelin judgment, the ECJ, without justification, completely departed from the concept of potential additional measures. ${ }^{52}$ It did not take into account that it may be crucial for a member state government to lay down stricter rules in order to meet the needs of its citizens. With regard to nuclear energy, the attitudes of the peoples in Europe vary significantly (see Part B.). Against the background of such fundamental policy choices, Scharpf rightly emphasizes that the "capacity of member states to comply with EU law reaches its limits when doing so would undermine their own legitimacy in relation to their national constituencies." ${ }^{153}$

\section{The Decisive Political Question}

From a political point of view, it is of minor importance whether or not $\S 364 a A B G B$ implies an illicit difference in treatment under Euratom law. However, the ECJ, when judging this issue, deemed it necessary to answer the crucial question of who ultimately decides the level of nuclear radiation protection in the EU multi-level system. Apparently, the Court was afraid that Euratom's health and safety policy and/or the EU's legal system in general could be weakened by national measures which aim at more rigorous protection than the EAEC's basic standards. ${ }^{54}$ Thus, it ruled that Euratom provides for a sufficient

\footnotetext{
${ }^{49}$ Grunwald, supra note 2; Grunwald, supra note 9; Serrano, supra note 11, at 17.

${ }^{50}$ Temelin, paras. 111-34.

${ }^{51}$ Case C-376/90, Commission v. Belgium, 1992 E.C.R. I-6153 (summary) [hereinafter Commission v. Belgium].

52 In fact, in the Temelin case the Court supported the view of the Commission which it had rejected in Commission v. Belgium.

${ }^{53}$ Scharpf, supra note 17 , at 19.

${ }^{54}$ If the ECJ had wished to avold a clear answer to the questions referred by the Landesgericht Linz, it could have simply ruled that the dispute does not fall within the scope of application of the EC Treaty. It deliberately did not so. See Temelin, paras. 81-86. Joerges identifies seven queries regarding the Temelín case:
}

(1) There is a horizontal conflict between two Member States. The Czech Republic has opted for; Austria has opted against, atomic 
nuclear safety regime, especially when it comes to cross-border disputes about the adequate level of precautionary measures. The Court's ruling strengthens the EAEC in general and the European Commission in particular ${ }^{55}$-at least on paper. If one takes a closer look, the ECJ's hierarchical approach (see Part E.Il.) is partly disadvantageous from the perspective of both input and output legitimacy. ${ }^{56}$ The same goes for competing approaches invoked by other actors involved in the Temelín dispute.

\section{E. Competing Modes of Governance}

Drawing on the Temelin case, there are four distinguishable approaches or modes of governance ${ }^{57}$ that can be used to decide cross-border disputes on the adequate level of nuclear radiation protection in the EU. This section analyzes, from the perspective of input and output legitimacy, some key advantages and disadvantages of unilateralism (Part E.I.), hierarchical supranationalism (Part E.II.), deliberative nationalism (Part E.III.) and deliberative supranationalism (Part E.IV.).

energy, Is the Czech Republic entitled to expose Austria to the risks of atomic energy? Is Austria entitled to impose its views on the Czech Republic? (2) There is a vertical conflict between European law and Austrian law if we assume that the EA-Treaty's encouragement of atomic energy trumps Austrian constitutional law. (3) There is also a vertical conflict if we assume that the economic freedoms are supreme. (4) There is a "dlagonal" conflict between the two levels of government if we assume that the EA-Treaty is incomplete and respects the autonomy of the Member States in the realm of atomic energy policy. (5) Can we read the European competence to establish safety standards as a resolution of the conflict, or is that a spurious response? (6) The most challenging conflict is temporal: Back in 1957, atomic energy was not a nightmare but a cherished future. How can the law get away from a Panglossian past? (7) Last, but not least: Quis judicabit? is the European Court of Justice legitimated to decide upon all this?

Christian Joerges, Unity in Diversity as Eurape's Vocation and Conflicts Law as Europe's Constitutional Form, TRANSSTATE WORKING PAPERS No. 148, 44 (2011). The remaining sections of this article mainly deal with queries (1) and (7).

${ }^{55}$ Schärf, supra note 16 , at 91 ; Schärf, supra note 31 , at 34 .

${ }^{55}$ On the concept of input and output legitimacy in the EU, see Scharpf, supra note 17, at 13-14; see also Arthur Benz \& Yannis Papadopoulos, Introduction. Governance and democracy: concepts and key issues, in GOVERNANCE and Democracy. Comparing national, European and International experiences, 1, 4-5 (Arthur Benz \& Yannis Papadopoulos eds., 2006).

${ }^{57}$ For an overview on governance research and modes of governance in the EU, see, for example, Arthur Benz \& Nicolai Dose, Governance-Modebegriff oder nützliches sozialwissenschaftliches Konzept?, in GOVERNANCEREgIEREN IN KOMPLEXEN Regelsystemen. EINE EINFUhrung 13 (Arthur Benz \& Nicolai Dose eds., 2d ed. 2010); Benz \& Papadopoulos, supra note 56; Fritz W. Scharpf, Notes Toward a Theory of Multilevel Governing in Europe (MPIfG Discussion Paper No. 00/5 2000) 


\section{Unilateralism}

According to the Land Oberösterreich, the dispute should be decided on the basis of Austrian standards since Austrian territory is affected by actual or potential damage resulting from the operation of the Temelín nuclear power plant. ${ }^{58}$ An eventual injunction handed down by an Austrian court should be enforced in the Czech Republic pursuant to Regulation (EC) No. 44/2001. 5 Such an approach can be labeled "unilateralism" because a member state seeks to unilaterally impose its standards on another member state. There is an important difference between unilateralism and mutual adjustment: ${ }^{60}$ the latter means that, despite external pressure, member states still more or less autonomously decide, e.g. Whether and how they engage in the regulatory competition characterizing the EU's common market.

Let us assume for a second that the Temelín case is decided according to this mode of governance. ${ }^{61}$ While unilateralism would ensure a high level of nuclear radiation protection for Austrian property owners and citizens (as they expect, see Part B.), Czech interests would be completely neglected. From the perspective of both input and output legitimacy, this approach would only be advantageous for the Austrian party. The unilateral approach apparently contradicts the legal principle of mutual recognition. ${ }^{62}$ Moreover, it disregards the "moral commitment to the 'inclusion of the other" ${ }^{63}$ in the EU multi-level polity. ${ }^{64}$

${ }^{58}$ Temelín, paras. 41-42.

${ }^{59} \mathrm{Cf}$. id. at para. 54 .

${ }^{60}$ On mutual adjustment in the EU as a distinct mode of governance, see Scharpf, supra note 57, at 11-13.

${ }_{51}$ Most probably, Czech courts would not enforce an eventual injunction since it would manifestly contradict Czech public policy. See Temelín, para. 61; Opinion of Advocate General Poiares Maduro, paras. 18-19.

${ }^{62}$ Cf. Möstl, supra note 41 , at 1231.

${ }^{63}$ Scharpf, supra note 17, at 31; see also Joerges, supro note 54, at 24.

${ }^{54}$ However, the Land Oberösterreich claimed that its action for an injunction was legitimized by the fact that it had been ignored by the Czech authorities. That is, it "was not able to participate in the authorisation procedure." Temelin, para. 56. Austria is of the opinion that the Czech Republic did not fulfill certain obligations under the "Melk agreement." See Hummer, supra note 19, at 531. In fact, each party argued that the other party violated the moral and/or legal principle to take the other into account. See Temelin, Opinion of Advocate General Poiares Maduro, para. 1. 


\section{Hierarchical Supranationalism}

The ECJ and the European Commission as well as the Czech, French and Polish governments take the view that the dispute should be decided on the basis of European standards since the EAEC provides for a sufficient level of nuclear radiation protection that has to be accepted by all member states. ${ }^{65}$ This mode of governance may be labeled "hierarchical supranationalism" because binding key decisions are made on the supranational level and member states are prohibited to invoke higher national standards, at least in the context of transnational disputes. ${ }^{66}$ While this approach implies a common solution to the dispute in question and thus prevents that a member state unilaterally imposes its standards on another member state (see Part E.I.), it is not without disadvantages. From the perspective of input legitimacy, the overwhelming will 'of the Austrian people (see Part B.) not to be endangered by nuclear power stations (especially suspect plants like Temelín ${ }^{67}$ ) is subordinated to a strict supranational order. The regulation of nuclear energy is such a politicized issue in most member states that one should not discuss "risks of politicization" ${ }^{\prime 68}$ but risks of underestimating already existing politicization. If skeptical European citizens feel that the EU forces them to accept extremely hazardous power plants in their neighborhood, the fragile legitimacy of the European polity could be seriously damaged, particularly since there is no "collective European identity that is strong enough to override [such fundamental] concerns of national self-interest." ${ }^{\prime 69}$

From the perspective of output legitimacy, the Court's attempt to present Euratom's health and safety policy as fully operative and effective is, at least to some extent, wishful thinking. In its landmark decision Commission v. Council (repeatedly cited in Temelin), ${ }^{70}$ the ECJ declared that the EAEC possesses, inter alia, "legislative competence to establish, for the purpose of health protection, an authorisation system which must be applied by the Member States." ${ }^{\prime 1}$ The Commission did not lose time and based two far-reaching

\footnotetext{
${ }^{65}$ Temelín, paras. 72-80, 135-36.

${ }^{66}$ The term "hierarchical supranationalism" draws on Scharpf's concept of "hierarchical direction." However, the latter refers to more or less autonomous supranational institutions (EC, Commission, European Central Bank) whereas "hierarchical supranationalism" also includes European institutions with close links to the member states such as the Council and the European Parliament. Cf. Scharpf, supra note 57, at 14-18.

${ }^{67}$ On the hybrid technology of the Temelin nuclear power plant and incidents since the plant started operating, see Hummer, supra note 19 , at 523.

${ }^{68}$ Giandomenico Majone, The Credibility Crisis of Community Regulation, 38 J. CoMmon MKT STUD. 273, 299 (2000).

${ }^{59}$ Scharpf, supra note 17 , at 22.

${ }^{70}$ Case C-29/99, Commission v. Council, 2002 E.C.R. I-11221 [hereinafter Commission v. Council].

${ }^{71} / d$. at para. 89
} 
proposals for Euratom directives on this judgment. ${ }^{72}$ However, the Council did not adopt these initiatives for many years. ${ }^{73}$ It finally accepted a significantly watered-down Nuclear Safety Directive in 2009. ${ }^{74}$ Despite the Euratom Treaty's explicit enabling provisions, it is obvious that various member states do not want the EAEC to play a major role in the field of nuclear safety. Thus, they continuously block necessary secondary law and supranational control mechanisms which could be in place for decades. Against this backdrop and dubious incidents involving the existing European radiation control system, ${ }^{75}$ one may question the Court's optimistic and uncritical view that Euratom provides for "the consistent and effective protection of the health of the general public against the dangers arising from ionising radiations. ${ }^{76}$

\section{Deliberative Nationalism}

Advocate General Maduro argued that the dispute should be decided on the basis of Austrian, Czech and European rules. From his point of view, Austrian courts are competent to assess whether the Czech authorization provides a sufficient protection for Austrian citizens and property owners. However, by doing this they have to take into account both European and Czech law and interests. First, they have to consider that the Czech authorization of the Temelín nuclear power plant complies with Euratom nuclear safety measures. These measures may already take into account Austrian interests to a satisfactory degree." In a second step, "the Austrian courts must take account of the benefits to the Czech Republic of the existence of this facility and cannot base its [their] decision solely on domestic interests." ${ }^{78}$ This approach is characterized by the balancing of different national as well as supranational standards and interests on member state level. Thus, it can be labeled "deliberative nationalism." "79

\footnotetext{
${ }^{72}$ See Christiane Trüe, Legislative Competences of Euratom and the European Community in the Energy Sector: the "Nuclear Package" of the Commission, 9 EUR. L. REV. 664 (2003).

${ }^{73}$ See Sauter, supra note 10.

${ }^{74}$ See Sebastian Wolf, Erklärungsfaktoren für die Entwicklung der europäischen Atomenerglepolitik jenselts akteurszentrierter Ansätze, 38 ÖSTERREICHISCHE ZEITSCHRIFT FÜR POLITIKWISSENSCHAFT 467, 476-77 (2009).

${ }^{75}$ For a critique of the European Community Urgent Radiological Information Exchange (ECURIE), see Hummer, supra note 19, at 551-53.

${ }^{76}$ Temelin, para. 112. In the German version of the judgment, the Court highlighted the "lickenlosen und wirksamen Gesundheitsschutz." Id. (emphasis added).

${ }^{77}$ Temelín, Opinion of Advocate General Poiares Maduro, para. 17.

${ }^{73}$ Id. para. 18.

79 The term "deliberative nationalism" draws on the concept of "deliberative supranationalism" developed by Joerges and Neyer. See Part E.IV. The main difference between these two approaches is where the process of deliberation takes place: at member state level (deliberative nationalism) or at EU level (deliberative supranationalism).
} 
Obviously, deliberative nationalism as a mode of governance is much more demanding than both unilateralism and hierarchical supranationalism. ${ }^{80}$ According to the latter approaches, either national law (unilateralism) or supranational law (hierarchical supranationalism) has to prevail. In contrast, deliberative nationalism seeks to balance rules and interests of different jurisdictions in order to find a solution that leads "each party to internalize in its own decision the interests of the other. ${ }^{\prime 81}$ This means, from the perspective of input legitimacy, that the respective will of Austrian and Czech citizens is not simply overruled. With regard to output legitimacy, the people in both Austria and the Czech Republic probably have to accept a limited implementation of their respective interests. Nevertheless, it seems that this mode of governance is more likely to achieve a moderate win-win situation in the Temelin dispute than unilateralism and hierarchical supranationalism. However, if Austrian courts, after balancing Austrian, Czech and European law and interests, actually refuse to recognize the Czech authorization, Czech authorities and courts are likely not to accept and enforce such a "biased" decision. "The key disadvantage of deliberative nationalism is that one member state may question the other member state's way of balancing all the interests at stake. A European solution could prevent such a dilemma, but hierarchical supranationalism has its own disadvantages (see Part E.II.). Against this background, a fourth approach not represented in the Temelin case will be discussed in the next section.

\section{Deliberative Supranationalism}

As was pointed out in the previous subsections, a unilateral decision to end the Temelin dispute is likely to increase the tensions between the two neighboring EU member states Austria and Czech Republic (Part E.I.). A simple hierarchical supranational solution based on the supremacy of EU or EAEC law risks to neglect the fact "that antinuclear politics is a part of the Austrian identity ${ }^{\prime \prime 33}$ (Part E.II.). Even if one party takes a deliberative approach and tries to balance all interests and rules at stake, the other party will probably not accept an outcome that contradicts its key interests (Part E.III.).

Against this backdrop, the concept of "deliberative supranationalism" ${ }^{84}$ seems to combine the advantages of both hierarchical supranationalism and deliberative nationalism: a

${ }^{80}$ Cf. Norbert Reich, Kernkraft ante portas der Gemeinschaftsfreiheiten, 20 EUROPÄISCHE ZEITSCHRIFT FÖR WIRTSCHAFTSRECHT 433 (2009).

${ }^{81}$ Temelín, Opinion of Advocate General Poiares Maduro, para. 1.

${ }^{82}$ Temelín, para. 61.

${ }^{83}$ Schärf, supra note 16 , at 79.

${ }^{84}$ This approach has been developed and defended by Joerges and Neyer. See, e.g., Christian Joerges, "Deliberative Supranationalism"-Two Defences, 8 EUR. L.J. 133 (2002); Christian Joerges \& Jürgen Neyer, From 
binding European solution on a deliberative basis. However, this mode of governance is even more demanding than deliberative nationalism. It requires, inter alia, (1) that all member states realize the trans-European dimension of the conflict and participate in problem solving, ${ }^{85}(2)$ that the two conflicting parties are willing to find (and implement) a compromise, ${ }^{86}(3)$ that majority voting is avoided, ${ }^{87}$ and (4) that supranational institutions support an unbiased decision-making process ${ }^{88}$ and control the enforcement of the decision. It is understandable that several national and supranational actors prefer a less demanding mode of governance such as hierarchical supranationalism, especially if it supports their policy interests in the respective conflict (see Czech Republic, France and Poland in the Temelin case) or generally strengthens their position in EU decision-making (Commission, ECJ).

\section{F. Conclusive Remarks: A Hypothetical Framework to Induce Deliberative Supranationalism}

The dispute about the safety of the Temelin nuclear power plant is a litmus test for the European nuclear energy policy. Jean Monnet and others hoped that Euratom would foster European integration (see Part A.), but today attitudes towards nuclear energy vary considerably from one member state to another (see Part B.). With regard to the Temelin conflict, there is so much distrust between Austria and the Czech Republic that a bilateral solution is not realistic. ${ }^{89}$ From a theoretical point of view, deliberative supranationalism seems to be the most promising approach to deal with fundamental conflicts in the EU multi-level polity since it aims at the "inclusion of the other" on supranational level (see Part E.IV.). Is there an institution that could exercise this function? Joerges regrets that

Intergovernmental Bargaining to Deliberative Political Processes: The Constitutionalisation of Comitology, 3 EUR. L.J. 273 (1997); Christian Joerges \& Jürgen Neyer, Transforming Strategic Interaction into Deliberative ProblemSolving: European Comitology in the Foodstuffs Sector, 4 J.EUR. PUB. PoL'Y 609 (1997); Christian Joerges \& Jürgen Neyer, "Deliberative Supranationalism" Revisited (EUI Working Paper LAW No. 2006/20 2006).

${ }^{85}$ Up until now, the other member states did nat show much interest in the dispute. Cf. Hummer, supra note 19, at 528 .

${ }^{86}$ Since its accession to the EU, it seems that the Czech Republic more or less ignores the Austrian concerns. On the other side, Austrians will only reluctantly accept the notion that they shall take into account Czech interests. See Reich, supra note 80.

${ }^{87}$ Particularly when it comes to issues of high political salience, the principle of unanimity may ensure input legitimacy. See Scharpf, supra note 17, at 13.

"The Commission participated in the "Melk process" but obviously failed to successfully mediate between the two conflicting member states.

${ }^{89}$ On the failed "Melk process," see Hummer, supra note 19, at 531. Since there is no "good deal of mutual trust and cooperation" and no "common regulatory philosophy," Majone's agency approach ("transnational regulatory network") does not seem to be a promising mode of governance for the issue in question. Cf. Majone, supra note 68 , at 297-98. 
Europe does not have a "higher legislative authority" like the US Congress; this usually means that the ECJ steps in since it does "not hesitate to take a decision. This is a disempowerment of politics by law." ${ }^{90}$

In the context of Euratom, the Council could act as a deliberative body with the task to solve structural problems underlying conflicts such as the Temelin case. However, the Council is not likely to take action if a significant number of member states do not feel affected and several countries as well as the Commission favor hierarchical supranationalism since European law seems to support their position. The existing legal framework in the EU does not frequently induce member state governments to engage in deliberation. One could imagine a multi-level polity in which all member states would only be entitled to the benefits of supranational law if they found unanimous solutions to fundamental conflicts. With regard to the Temelin dispute, this could mean that without a political compromise, states like the Czech Republic would not have the right to invoke European law in order to sell and transfer their electricity generated by nuclear power to other member states (i.e. the economic freedoms would be partially suspended). On the other side, Austria and other anti-nuclear countries would not be allowed to invoke EU law (e.g. secondary law on the recognition and enforcement of judgments in other member states) in order to extend their high technical standards to countries like the Czech Republic if they did not accept the basic notion that they may not impose their total ban of nuclear power plants on other member states. ${ }^{91}$

If European law favors just one party in a conflict, game-theoretic considerations ${ }^{92}$ suggest that this party has no incentive to take the interests of the other parties involved into account. This is a structural shortcoming of the EU's existing legal framework since a mode of governance derives "its legitimacy from the quality of the procedures guiding its decision-making process." ${ }^{\prime 93}$ The ECJ increasingly decides on fundamental conflicts between national core policies and rather rarely applies a deliberative conflicts-law approach. $^{94}$ As in the Temelín case, it regularly promotes hierarchical supranationalism. Advocates of this rather parsimonious mode of governance featuring the doctrine of supremacy of EU law should not underestimate the fact that "the Court is now intervening

\footnotetext{
${ }^{90}$ Joerges, supra note 54 , at 45 .

${ }^{91}$ As Joerges puts it: "The French are not entitled to expose the Germans to the risks of nuclear energy. The same is true vice versa: The Germans cannot impose their Energiewende on the rest of Europe." Christian Joerges, The timeliness of direct democracy in the EU, conference contribution, unpublished draft as of 28 June $2011,7$.

${ }^{92}$ See generally FRITZ W. SCHARPF, GAMES REAL ACTORS PLAY. ACTOR-CENTERED INSTITUTIONALISM IN POLICY RESEARCH (1997).

${ }^{93}$ Joerges, supra note 54 , at 47.

${ }^{94}$ On the conflicts-law perspective, see Joerges, supra note 54 , at 23-28, 45-50 (citing further references).
} 
in areas that are of crucial importance for the maintenance of democratic legitimacy in EU member states." ${ }^{95}$

\section{G. Epilogue: Fukushima, Euratom and Governance in Case of Serious Nuclear Accidents}

Several months after the maximum credible accident at the Fukushima nuclear power plant, the Japanese authorities and the Tokyo Electric Power Company (TEPCO, the owner of the power station) still do not have full control of three damaged reactors and are unable to prevent the daily environmental exposure to high doses of radiation. ${ }^{96}$ Tens of thousands of people had to leave their hometowns, and many of them will probably never be able to return to their houses. ${ }^{97}$ Due to this disaster, German and Swiss governments, as well as most Japanese citizens, changed their attitudes towards nuclear energy. Additionally, the Italians overwhelmingly rejected a government initiative to produce nuclear energy in Italy by means of referendum. ${ }^{98}$ However, it seems that most states with nuclear power plants-including Japan-do not intend to (significantly) change their nuclear energy policies. ${ }^{99}$ At a high-level conference on nuclear safety in June 2011, although the ministers of the IAEA member states stressed the need to learn lessons from the accident and to draw up an action plan, they did not adopt legally binding instruments. ${ }^{100}$ The European Commission enacted an emergency measure to protect consumers in the EU from contaminated Japanese food and feed. ${ }^{101}$ Risk and safety assessments (so-called "stress tests") of all 143 nuclear power plants in the EU started on 1 June 2011, under the auspices of the Commission and the European Nuclear Safety Regulators' Group (ENSREG). The process involves, inter alia, pre-assessments (by plant operators), national reports (by the national regulators), peer reviews (evaluation teams

\footnotetext{
${ }^{95}$ Scharpf, supro note 17 , at 30 .

${ }^{96}$ For detailed information about this nuclear accident, see, for example, the International Atomic Energy Agency's (IAEA) website which is regularly updated: http://www.iaea.org/newscenter/focus/fukushima/.

${ }^{97}$ Michael Bauchmüller, Akkurates Chaos, SÖdDeutsche Zeitung, 17 June 2011, at 3.

${ }^{98}$ Andrew Willis, Italians reject nuclear energy in further blow to Berlusconi, EUOBSERVER (14 June 2011, 9:26 AM), http://euobserver.com/885/32481.

${ }^{99}$ On the exemplary case of the United Kingdom, see Andreas Oldag, Fukushima, kein Problem, SODDEUTSCHE ZEITUNG, 2/3 July 2011, at 26.

100 See Declaration by the IAEA Ministerlal Conference on Nuclear Safety in Vienna on 20 June 2011, http://www.iaea.org/Publications/Documents/infcircs/2011/infcirc821.pdf (last visited 10 Aug. 2011).

${ }^{101}$ Commission Implementing Regulation (EU) No 297/2011 of 25 March 2011, Imposing special conditions governing the import of feed and food originating in or consigned from Japan following the accident at the Fukushima nuclear power station, 2011 0.J. $(L \mathrm{80)} 5$. The measure draws on Euratom Regulations laying down maximum permitted levels of contamination adopted after the Chernobyl disaster. For a harsh critique pointing at the lifting of thresholds, see Patrick Illinger, Panikmache für Anfänger, SüdDEUTSCHE ZEiTuNG, 31 Mar. 2011 , at 4.
} 
consisting of one Commission representative and six ENSREG members), and the publication of both the national reports and the results of the peer reviews. ${ }^{102}$

Japan is an IAEA member state, but it is not a member of a supranational organization like the EAEC. If a nuclear disaster like Fukushima happened in an EU member state, would Euratom provide specific means to better cope with the situation? In the first days after the accident, the Japanese authorities were criticized because they only reluctantly published scarce information regarding levels of nuclear radiation and contamination. Moreover, they may have decided too late to evacuate ten thousands of people and trusted too long in TEPCO's problem-solving abilities. With regard to these points, Euratom appears to possess promising instruments. First, the Commission is always informed about the levels of radioactivity in the member states according to Art. 35 and 36 of the Euratom Treaty, as well as the European Community Urgent Radiological Information Exchange. The Commission is entitled to access and scrutinize member state facilities which monitor levels of radioactivity. Thus, if a member state intended to withhold information in the event of a serious nuclear accident, the Commission could inform the public in the EU and neighboring countries. Second, Art. 38 Euratom Treaty provides that

In cases of urgency, the Commission shall issue a directive requiring the Member State concerned to take, within a period laid down by the Commission, all necessary measures to prevent infringement of the basic standards and to ensure compliance with regulations.

Should the State in question fail to comply with the Commission directive within the period laid down, the Commission or any Member State concerned may forthwith, by way of derogation from Articles 258 and 259 of the Treaty on the Functioning of the European Union, bring the matter before the Court of Justice of the European Union.

From a governance perspective, Art. 38 Euratom Treaty establishes strong hierarchical supranationalism in cases of serious nuclear accidents. The Commission is authorized to instruct reluctant, overwhelmed or incompetent member state authorities in order to protect EU citizens from high doses of nuclear radiation. It may ask advisory bodies or member states for opinions and data, but when deciding on an emergency directive, the

\footnotetext{
${ }^{102}$ For several documents and detailed information about the EU nuclear stress tests, see Stress Tests, EUROPEAN COMmISsION, http://ec.europa.eu/energy/nuclear/safety/stress_tests_en.htm (last visited 10 Aug. 2011).
} 
Commission is not controlled by or dependent on another political institution (e.g. the Council) and may quickly ask the ECJ for support. Unsurprisingly, this comprehensive legal competence to enact extensive emergency measures (Notverordnungsrecht) is confined to serious cases of urgency. As was pointed out in the previous sections, hierarchical supranationalism is not and should not be mandatory when it comes to decide on general Euratom policies. The nuclear stress tests mentioned above could give rise to more deliberative modes of policy-making in this particular field of European multi-level policy. It is not the first time that a nuclear disaster outside of the EU has triggered new EAEC activities (see Part A.). The lack of consensus among the EU member states regarding nuclear energy may justify a revision or even the abolishment of the Euratom Treaty, ${ }^{103}$ but the Treaty's remarkable supranational instruments designed to deal with long-term crossborder problems such as nuclear radiation and proliferation of nuclear weapons should not be called into question. ${ }^{104}$

\footnotetext{
${ }^{103}$ Joerges, supra note 91, at 5-6, discusses the applicability of the new European Citizens' Initiative with regard to a revision of the Euratom Treaty.

${ }^{104}$ For similar conclusions see generally Grunwald, supra note 2 and Wolf, supra note 11.
} 